\title{
Ulk4 Is Essential for Ciliogenesis and CSF Flow
}

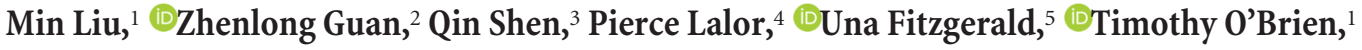 \\ Peter Dockery, ${ }^{4}$ and Sanbing Shen ${ }^{1}$ \\ ${ }^{1}$ Regenerative Medicine Institute, School of Medicine, National University of Ireland Galway, Galway, Ireland, ${ }^{2}$ Department of Physiology, College of Life \\ Science, Hebei Normal University, Shijiazhuang 050024, China, ${ }^{3}$ Center for Stem Cell Biology and Regenerative Medicine, Center for Life Sciences, School of \\ Medicine, Tsinghua University, Beijing 100084, China, ${ }^{4}$ Anatomy Department, School of Medicine, National University of Ireland, Galway, Ireland, and \\ ${ }^{5}$ National Centre for Biomedical Engineering Science, Galway Neuroscience Centre, National University of Ireland, Galway, Ireland
}

Ciliopathies are an emerging class of devastating disorders with pleiotropic symptoms affecting both the central and peripheral systems and commonly associated with hydrocephalus. Even though ciliary components and three master transcriptional regulators have been identified, little is known about the signaling molecules involved. We previously identified a novel gene, Unc51-like-kinase 4 (ULK4), as a risk factor of neurodevelopmental disorders. Here we took multidisciplinary approaches and uncovered essential roles of Ulk4 in ciliogenesis. We show that Ulk4 is predominantly expressed in the ventricular system, and Ulk $4^{\text {tmIa/tmla }}$ ependymal cells display reduced/ disorganized cilia with abnormal axonemes. Ulk $4^{\text {tmla/tmla }}$ mice exhibit dysfunctional subcommissural organs, obstructive aqueducts, and impaired CSF flow. Mechanistically, we performed whole-genome RNA sequencing and discovered that Ulk4 regulates the Foxj1 pathway specifically and an array of other ciliogenesis molecules. This is the first evidence demonstrating that ULK4 plays a vital role in ciliogenesis and that deficiency of ULK4 can cause hydrocephalus and ciliopathy-related disorders.

Key words: ciliogenesis; CSF; hydrocephalus; hypomorph mouse; neurodevelopmental disorder; Ulk4

\section{Significance Statement}

Ciliopathies are an emerging class of devastating disorders with pleiotropic symptoms affecting both the central and peripheral systems. Ciliopathies are commonly associated with hydrocephalus, and Unc51-like-kinase 4 (Ulk4) has been identified as one of 12 genes causing hydrocephalus in mutants. Here we uncover an essential role of Ulk4 in ciliogenesis. Ulk4 is predominantly expressed in the ventricles, and mutant ependymal cells display reduced/disorganized/nonfunctional motile cilia with abnormal axonemes and impaired CSF flow. Ulk4 modulates expression of the master regulator of ciliogenesis, Foxj1, and other ciliogenesis molecules. This is the first report demonstrating a vital role of Ulk4 in ciliogenesis. ULK4 deficiency may be implicated in human hydrocephalus and other ciliopathy-related disorders.

\section{Introduction}

Ciliopathies, which are associated with neurodevelopmental disorders of pleiotropic clinical symptoms, include Joubert syn-

Received Feb. 16, 2016; revised May 14, 2016; accepted May 19, 2016.

Author contributions: M.L., Z.G., Q.S., P.L., U.F., T.O., P.D., and S.S. designed research; M.L. and S.S. performed research;S.S. contributed unpublished reagents/analytic tools; M.L., Z.G., Q.S., P.L., U.F., T.O.,P.D., and S.S. analyzed data; M.L., Z.G., Q.S., P.L., U.F., T.O., P.D., and S.S. wrote the paper.

This work was supported by Science Foundation Ireland (Grant 09/SRC/B1794s1 and 13/IA/1787 to S.S.) and the National University of Ireland Galway (Grant RSU002 to S.S.); We thank the staff of the Bio-Resources Unit, in particular Drs. Yolanda Garcia and Cathal O'Flatharta, for the support and assistance of experimental procedure. We would also like to thank the Knockout Mouse Project Repository (www.KOMP.org) and the Mouse Biology Program (www.mousebiology.org) at the University of California, Davis, for Ulk4 ${ }^{+/ t m 7 a}$ breeding pairs. We also want to acknowledge the scientific and technical assistance of Dr. Kerry Thompson of the Centre for Microscopy \& Imaging at the National University of Ireland. This facility is funded by the National University of Ireland Galway and the Irish Government's Programme for Research in Third Level Institutions, Cycles 4 and 5, National Development Plan.

The authors declare no competing financial interests.

Correspondence should be addressed to either of the following: Sanbing Shen, Regenerative Medicine Institute, School of Medicine, National University of Ireland Galway, Galway, Ireland. E-mail: sanbing.shen@nuigalway.ie; or Zhenlong Guan, Department of Physiology, College of Life Science, Hebei Normal University, Shijiazhuang 050024, China. E-mail: zlguan60@mail.hebtu.edu.cn. drome, Bardet-Biedl syndrome, Meckel-Gruber syndrome, oral-facial-digital syndrome type 1 , and nephronophthisis, all of which are commonly associated with hydrocephalus (Lee and Gleeson, 2011). Handedness, linked to dyslexia and schizophrenia, is also shown to involve ciliopathies (Brandler and Paracchini, 2014). MIPT3, an interactive protein of disrupted-in-schizophrenia 1 (DISC1), which is truncated in a large Scottish schizophrenic family (Millar et al., 2000), functions synergistically with the Bardet-Biedl syndrome protein Bbs4 and plays a critical role in assembling intraflagellar transport particle complexes (Li et al., 2008). Remarkably, when 41 candidate genes associated with schizophrenia, bipolar affective disorder, autism spectrum disorder, and intellectual disability are investigated, 23 are found to regulate cilium length in cultured cells (Marley and von Zastrow, 2012). 
We recently demonstrated that the Unc51-like-kinase 4 (ULK4) gene is a rare risk factor for schizophrenia, autism, and bipolar disorder (Lang et al., 2014). Our unpublished data show that ULK4 is deleted in some patients with heterogeneous clinical features, including developmental delay, language delay, and severe intellectual disability (Liu et al., 2016, in press). Depleted ULK4 expression in neuroblastoma cells disrupts microtubular composition, compromises neuritogenesis and cell motility, and modulates multiple signaling pathways, which are associated with schizophrenia. Ulk4 is developmentally regulated by morphogens, and there is a switch in Ulk4 isoforms during mouse brain formation and neuronal maturation. Targeted Ulk4 deletion compromises corpus callosum integrity in mice (Lang et al., 2014), and agenesis of the corpus callosum is a frequent brain disorder found in $>80$ human congenital syndromes, including ciliopathies and neurodevelopmental disorders (Laclef et al., 2015).

To investigate the role of Ulk4 during brain formation, we recently characterized Ulk4 gene expression during Xenopus development, and found coexpression of Ulk4 mRNA with Sox3 (a neural progenitor cell marker) and Blbp (a radial glial marker) in the ventricular zone of the forebrain (Domínguez et al., 2015). To understand the consequence of genetic lesions, here we systematically investigated $U l k 4^{\text {tmla/tmia }}$ mice. We demonstrate that Ulk4 is predominantly expressed in the cells lining the ventricles and is essential for ciliogenesis. Ulk $4^{\text {tmla/tmla }}$ mice exhibit dysfunctional subcommissural organs (SCOs), obstructive aqueducts, and noncommunicating hydrocephalus. The CSF flow is impaired, and Ulk4 ${ }^{\text {tmla/tmla }}$ ependymal cells display reduced/disorganized/dysfunctional cilia with abnormal axonemes, which are required for coordinated beating of ependymal cilia and directional flow of CSF. Furthermore, we present the molecular mechanism that Ulk4 may regulate expression of Foxj1, a master switch of ciliogenesis, and numerous other ciliogenesis genes. Therefore, our findings indicate that Ulk4 may act as a scaffold protein regulating different processes of ciliogenesis and coordinated ciliary beating, and ULK4 may be associated with human diseases of heterogeneous clinical symptoms in relation to cilia dysfunction.

\section{Materials and Methods}

Ulk4 hypomorph mice. The DNA sequence of the knock-out-first construct for creating the $U l k 4^{t m l a(K O M P) W t s i}$ (shortened as $U l k 4^{t m l a}$ in this article) mutants was published online (http://www.ncbi.nlm.nih.gov/ nuccore/JN950132.1). In the targeted allele, the intron 6 of sequence $5^{\prime}$-tctgtctgaagaaaggaggggccgccaggatcag- $3^{\prime}$ was replaced by the FRTEn2SA-IRES-LacZ-PA-hBactP-Neo-PA-FRT-loxP cassette, so that a fusion mRNA containing Ulk4 exons 1-6 and En2SA-IRES-LacZ-PA could be transcribed. The intron 7 sequence of $5^{\prime}$-cagcctcctgcactgcgattacagat caataccac- $3^{\prime}$ was replaced by a second loxP site, to enable deletion of the critical exon 7 (76 bp) by the Cre-LoxP system if needed.

The Ulk4 mutant strain was created from ES cell clone EPD0182_ 4_E12 generated by the Wellcome Trust Sanger Institute and made into mice by the Knockout Mouse Project (KOMP) Repository (www. KOMP.org) and the Mouse Biology Program (www.mousebiology.org) at the University of California, Davis. Methods used to create the (CHORI/Sanger/UC Davis)-targeted alleles were published previously (Skarnes et al., 2011). Breeding pairs of Ulk4 ${ }^{+/ t m l a}$ mice on C57BL/6N background were purchased from the KOMP Repository.

All experimental procedures were approved by both the Irish Department of Health and Children in accordance with Cruelty to Animals Act of 1876 with license number B100/4504; and by the institutional Animal Care and Research Ethics Committee with certificate number 12/SEP/02. $U l k 4^{\text {tm Ia/tmla }}$ and wild-type (WT) littermates were obtained from $U l k 4^{+/ t m l a} \times U l k 4^{+/ t m l a}$ mating. Each mouse was genotyped by genomic
PCR with two pairs of primers at the same time. The WT allele was detected by a 271 bp DNA fragment using Ulk4EndE7For (5' -TAACTT GCTGGACGGATTGCTG-3' in exon 7) and Ulk4EndIn7Rev (5'-TGA TCTGTAATCGCAGTGCAGG-3' ${ }^{\prime}$, nested within the sequence of $5^{\prime}$-CAG CCTCCTGCACTGCGATTACAGATCAATACCAC-3' deleted in the $U l k 4^{\text {tm la }}$ allele). The mutant allele was identified by a 621 bp PCR fragment using Ulk4KOMPKOFor (5'-GAGATGGCGCAACGCAATTA ATG-3', which was present only in the synthetic cassette) and Ulk4KOMPKORev (5'-CTGAGGAGACAATGTAACCAGC-3' from intron 7).

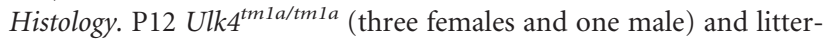
mate controls (one female and three males) were deeply anesthetized and intracardially perfused with $20 \mathrm{ml}$ of $4 \%$ paraformaldehyde (PFA) in PBS. The brains were dissected, postfixed in $4 \%$ PFA for $24 \mathrm{~h}$, and embedded into paraffin blocks. Serial coronal sections at $10 \mu \mathrm{m}$ were produced with a microtome (SM2000R, Leica Instruments), stained with hematoxylin and eosin (H\&E) and imaged under a bright-field microscope (IX41, Olympus) equipped with a camera.

CSF circulation assay. Three Ulk $4^{\text {tmla/tmla }}$ (one female and two males) and four littermate controls (two females and two males) postnatal day (P) 12 mice [three were anesthetized by intraperitoneal injection of ketamine $(150 \mathrm{mg} / \mathrm{kg}) / x y l a z i n e(15 \mathrm{mg} / \mathrm{kg})]$. The 30 gauge needle attached to a $10 \mu \mathrm{l}$ glass syringe was positioned at $0.1 \mathrm{~mm}$ posterior and $1.0 \mathrm{~mm}$ lateral to the bregma on the head. Five microliters of Evans blue dye (4\% in PBS) were slowly injected into the lateral ventricle (LV) of mice, which were killed 20 min later. Whole brains with a portion of the spinal cord were dissected and fixed in 4\% PFA. Coronal sections at $1 \mathrm{~mm}$ thickness were generated by tissue chopper $48 \mathrm{~h}$ later. Images at $1 \times$ magnification were captured by a stereomicroscope with a digital camera.

$X$-gal staining. Five P14 male mice were perfused, and brains were dissected, postfixed for $10 \mathrm{~min}$ in 4\% PFA, and washed in PBS twice for 5 min. They were cryoprotected in $30 \%$ sucrose in PBS overnight at $4^{\circ} \mathrm{C}$ until sinking to the bottom of the tube, embedded in Optimal Cutting Temperature compound, and immersed in isopentane bath prechilled with liquid nitrogen. The samples were sectioned at $30 \mu \mathrm{m}$ on a cryostat and mounted onto precoated slides. The sections were postfixed in $4 \%$ PFA for $10 \mathrm{~min}$ on ice, rinsed in PBS on ice for $2 \times 10 \mathrm{~min}$, and washed in PBS containing $2 \mathrm{~mm} \mathrm{MgCl} 2,0.02 \%$ Nonidet P- $40,0.01 \%$ sodium deoxycholate for $10 \mathrm{~min}$ on ice. The sections were incubated in the dark with X-gal (5-bromo-4-chloro-3-indolyl- $\beta$-D-galactoside) staining solution $(1 \mathrm{mg} / \mathrm{ml} \mathrm{X}$-gal, $5 \mathrm{~mm}$ potassium ferricyanide, $5 \mathrm{~mm}$ potassium ferrocyanide, $2 \mathrm{~mm} \mathrm{MgCl} 2,0.02 \%$ Nonidet P-40, 0.01\% sodium deoxycholate in PBS) overnight at $37^{\circ} \mathrm{C}$. The slides were then washed in PBS for $2 \times 5 \mathrm{~min}$ at room temperature, quickly rinsed in distilled $\mathrm{H}_{2} \mathrm{O}$, and counter-stained for $30 \mathrm{~s}$ in the eosin. They were subsequently washed in distilled $\mathrm{H}_{2} \mathrm{O}$ for $3 \times 5 \mathrm{~min}$, dehydrated through methanol ( 5 min each in 50,70 , and $100 \%$ methanol), cleared for $2 \times 5 \mathrm{~min}$ in xylene, and mounted with mount medium (Sigma-Aldrich).

Immunohistochemistry. P12 juvenile mutants (three females and one male) and WT littermates (one female and three males) were killed with overdoses of sodium pentobarbitone. Brains were postfixed in PBS containing $4 \%$ PFA at $4^{\circ} \mathrm{C}$ overnight, embedded in paraffin, and sectioned at $10 \mu \mathrm{m}$. The sections were immunostained using primary mouse monoclonal antibody against acetylated $\alpha$-tubulin (1:1000; Sigma-Aldrich) and secondary goat anti-mouse antibody conjugated to Alexa Fluor 555 (1:500; Cell Signaling Technology), and mounted with mounting medium containing DAPI (Sigma-Aldrich).

Scanning electron microscopy. P18 mice were perfused with $2.5 \%$ glutaraldehyde/2\% PFA in PBS and brains postfixed in $2.5 \%$ glutaraldehyde/2\% PFA in $0.1 \mathrm{~m}$ sodium cacodylate/ $\mathrm{HCl}$ buffer, $\mathrm{pH} 7.2$, overnight at $4^{\circ} \mathrm{C}$. LVs were exposed by dissection under stereomicroscope. After dehydration through graded alcohols, tissue samples were transferred to hexamethyl disilizane for $2 \times 15 \mathrm{~min}$. The samples were then allowed to dry overnight in a fume hood, fixed to metal stubs using silver DAG paint, gold sputter coated, and viewed on a Hitachi S2600N variablepressure scanning electron microscope.

Transmission electron microscopy. LV walls were dissected from P18 brains fixed in $2.5 \%$ glutaraldehyde $/ 2 \%$ paraformaldehyde $/ 0.1 \mathrm{M}$ sodium cacodylate/ $\mathrm{HCl}$ buffer, $\mathrm{pH} 7.2$, overnight at $4^{\circ} \mathrm{C}$. Tissues were subse- 
quently immersed in secondary fixative solution containing $1 \%$ osmium tetroxide in $0.1 \mathrm{~m}$ sodium cacodylate/ $\mathrm{HCl}$ buffer, $\mathrm{pH} 7.2$, for $4 \mathrm{~h}$. They were then dehydrated through a series of graded alcohols $(50,70,90,95$, and $100 \%$ ), placed in propylene oxide, and transferred to a series of resin and propylene oxide mixtures (50:50, 75:25, pure resin). Finally, tissues were transferred to flat embedding molds, clearly labeled, and placed in $65^{\circ} \mathrm{C}$ oven for $48 \mathrm{~h}$ to polymerize. After polymerization, blocks were sectioned at $100 \mathrm{~nm}$, lifted onto $3 \mathrm{~mm}$ copper grids, and stained for 30 $\min$ in $1.5 \%$ aqueous uranyl acetate for $10 \mathrm{~min}$ in lead citrate. Sections were dried and viewed on the Hitachi H7000 transmission electron microscope.

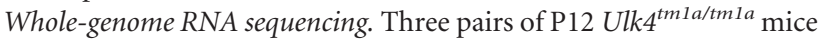
and WT controls were killed, and cortexes were quickly dissected and snap frozen in liquid nitrogen. RNA was extracted using RNeasy Kit (Qiagen) according to the manufacturer's instructions. RNA concentration was determined by the NanoDrop spectrophotometer. Equal amounts of RNA ( $\sim 6 \mu \mathrm{g} /$ mouse, $n=3$ each) were sent to BGI for whole-genome RNA sequencing. Libraries were constructed to convert RNA into cDNA, and quantitative RNA sequencing was performed by using the Illumina HiSeq2000 next-generation sequencer. Using bioinformatics tools and databases, 19,652 genes were identified from the P12 mouse cortex.

Relative gene expression was quantified and normalized in a format of FPKM (fragments per kilobase of transcript per million mapped reads). $P$ values of multiple testing and false discovery rates (FDRs) were analyzed and supplied by BGI. We also used one-way ANOVA to statistically analyze the differential expression with two tails. $p<0.05$ indicates statistical significance. The 414 cilia-associated genes were further analyzed statistically, and 34 Ulk 4 targets were analyzed with the STRING database for pathway association and protein-protein interaction.

Quantitative RT-PCR. Quantitative RT-PCR (qRT-PCR) was performed to validate expression of key Ulk4 targets detected by wholegenome RNA sequencing. Single-strand cDNA was synthesized from P14 cortical RNA of WT and Ulk $4^{\text {tmla/tmla }}$ mice. Triple qRT-PCRs were performed for each primer pair. GapdhFOR 5'-CTCATGACCACAGTC CATGC-3' and GapdhREV 5'-CACATTGGGGGTAGGAACAC-3' were used as cDNA loading control for each qRT-PCR plate. The Ulk4 RT-PCR primers were Ulk4E6FOR 5'-CCCCATTCTTCTCAGAAA CG-3' and Ulk4E8REV 5'-GTCTTTCCAGAATGGGTGCT-3' (197 bp); Ulk4E21For 5' -TTGATAGTCCGTCCACTCCC-3' and Ulk4E23Rev 5' CATGGGGAGACACATCTTCA-3' (189 bp); and Ulk4E34FOR 5'CCCAGAGAACATGGTGACCT-3' and Ulk4E36REV 5' -CGATAGTGT CGACGGGTGAG-3' (197 bp). Other primers include Foxj1FOR 5' GGCCACCAAGATCACTCTGT-3' and Foxj1REV 5'-CTTCTTGAAG GCCCCACTGA-3' (223 bp); Rfx3FOR 5'-TGCTAGCTTTGGCTCCT TTC-3' and Rfx3REV 5'-GATTTCCGGGAGATACAGCA-3' (152 bp); Vangl2FOR 5' -GCAGGAAGAGGAGCAGAAGA-3' and Vangl2REV 5' AATGCAGAACTCCAGGTGCT-3' (166bp);Pcm1For5' -TCCTGTGGA CATCCAGACTTC- $3^{\prime}$ and Pcm1REV 5'-GCGAGTCCTTATGGGTA GCA-3' (233 bp); Tubb4aFOR 5'-GGTCAATGCGGTAACCAGAT-3' and Tubb4aREV 5'-CACGGCTCTGGGAACATAGT-3' (165 bp); Rsph9FOR 5' -CCACTTCAGGGAGGCTATTG-3' and Rsph9REV 5'GAGCGTGGTAGAAGGTGAGG-3' (194bp);GsnFOR5'-GACTCTTTG CCTGCTCCAAC-3' and GsnREV 5'-TTGCTGGATCTGTCTCGA TG-3' (207 bp); Poc5FOR 5'-CAGGTCGGTCTGATTTTGGT-3' and Poc5REV 5' -CTGCTTTCAGGATGGATGGT (172 bp); Cep120FOR 5' AAACAGCAGGAGGAGTTGGA- ${ }^{\prime}$ and Cep120REV $5^{\prime}$-GCTTCCCAC TTGCAATCTCT-3' (172 bp); Kif5aFOR 5' -TCCTACCAGAAGGCCAA CAT-3' and Kif5aREV 5' -CTGCAGCTACCTGAAAGTGC-3' (178 bp); Spag6FOR 5' -ACATGTTGTTGGGCAGTTCAG-3' and Spag6REV 5' TTGGTAGCTGTCCACCCTCT-3' (226bp); and B9d2FOR 5' -TTCTCG GAAAGCAGCCTCTT-3' and B9d2REV 5' -TAGCGAAGTGCAGGTCA ATG-3' (154 bp). Relative RNA abundance in the Ulk4 $4^{\text {tmla/tmla }}$ cortex was calculated using $2^{\Delta \Delta \mathrm{Ct}}$, with average expression level of the corresponding gene in the WT littermates as $100 \%$. The data were presented as mean $\pm \mathrm{SEM}, n=3$ each $\left({ }^{*} p<0.05,{ }^{* *} p<0.01\right)$.

\section{Results}

Ulk4 deficiency causes growth retardation and preweaning loss

The Ulk4 mutant strain (Ulk4 $\left.4^{+/ t m l a}\right)$ was created by the KOMP Repository using the knock-out-first strategy (Fig. $1 A, B$ ). A cassette of FRT-En2SA-IRES-LacZ-PA-hBactP-Neo-PA-FRT-loxPExon7-loxP was inserted into intron 6, so that Ulk4 exons 1-6 could be spliced with En2SA-IRES-LacZ-PA to generate a chimeric Ulk4-SA-IRES-LacZ-PA mRNA. Although a polyA signal was followed the lacZ reporter gene, the En 2 splice acceptor site might not be fully efficient to knock-out Ulk4 gene completely. We evaluated Ulk4 mRNA expression in the Ulk4 ${ }^{\text {tm la/tmla }}$ mutants by qRT-PCR, using primers derived from the targeting region (exon $6-8$ ), the middle (exon 21-23), and the 3 ' -end of the Ulk4 gene (exon 34-36). The Ulk4 mRNA expression was reduced to $4.0 \pm$ 24.6\% $(p<0.01, n=3$ each; Fig. $1 D), 15.8 \pm 23.5 \%$ ( $p=0.01$; Fig. $1 E)$, and $22.8 \pm 8.9 \%(p=0.02$; Fig. $1 F)$ respectively in Ulk $4^{\text {tmla/tmla }}$ mice, showing an average $78-96 \%$ reduction of Ulk4 expression in the mutants. It is unknown whether the Ulk4 mRNA is generated from the leaky system of En2SA and/or from natural Ulk4 splicing variants using alternative promoter(s). It is also unclear whether they encode functional proteins. Nevertheless, these data demonstrate that the Ulk $4^{\text {tmla/tmla }}$ strain is a "hypomorph" model, not a "null" mutant. This further highlights the importance of the Ulk4 gene for brain development and function, given that $78-96 \%$ depletion of Ulk4 mRNA already resulted in striking phenotypes described in this article.

To investigate Ulk4 gene function, we first bred Ulk4 $4^{+/ t m 1 a}$ (Fig. $1 A-C)$ males with WT $\left(U l k 4^{+/+}\right.$) females and observed the expected Mendelian ratio of $U l k 4^{+/ t m l a}$ mice in offspring. For example, 117 pups were born from 19 litters with a standard litter size for C57BL/6N (6.2 \pm 0.6 , mean \pm SEM). Of the $111(95 \%)$ that survived to weaning, 52 were WT and 59 were heterozygous $U l k 4^{+/ t m l a}$. Therefore, deletion of one copy of Ulk4 gene did not affect mouse survival, sexual development, or reproduction.

However, $U l k 4^{+/ t m l a} \times U l k 4^{+/ t m l a}$ mating showed a significant preweaning loss. Among the 82 pups born from 12 litters (6.8 $\pm 0.5 /$ litter), only $63(76.8 \%)$ survived to weaning, with a

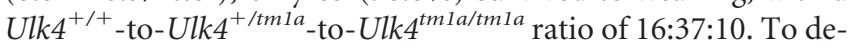
termine whether $U l k 4^{\text {tm la/tmla }}$ mice were embryonic lethal, we genotyped four litters of 28 pups (seven per litter) at birth (P0), and detected a $U l k 4^{+/+}: U l k 4^{+/ t m 1 a}: U l k 4^{\text {tmla/tm1a }}$ ratio of 9:11:8, showing that $U l k 4^{\text {tmla/tmla }}$ mice were not under-represented at birth. Subsequent genotyping further confirmed a Mendelian ratio of Ulk $4^{\text {tmla/tm1a }}$ mice at birth, but they rarely survived to P28.

Ulk $4^{\text {tmla/tmla }}$ mice displayed marked growth retardation. At P12, their body weight was $5.10 \pm 0.65 \mathrm{~g}(n=5, p<0.01), \sim 30 \%$ lighter than that of $U l k 4^{+/+}(7.10 \pm 0.15 \mathrm{~g}, n=12$; Fig. $1 E-G)$ or Ulk $4^{+/ t m l a}$ littermates $(7.20 \pm 0.21 \mathrm{~g}, n=12)$. However at P0, they $(1.52 \pm 0.02 \mathrm{~g}, n=5)$ did not differ from WT $(1.53 \pm 0.04 \mathrm{~g}$, $n=8$; Fig. $1 H)$ or $U l k 4^{+/ t m l a}(1.51 \pm 0.04 \mathrm{~g}, n=9)$ mice. Therefore, the Ulk4 gene is essential for postnatal growth and survival.

\section{Ulk $4^{\text {tmla/tmla }}$ mice develop hydrocephalus}

All Ulk $4^{\text {tmla/tmla }}$ mice exhibited hydrocephalic appearance with domed-shaped heads 2 weeks after birth (Fig. $1 F$, arrow). To investigate the neuropathology, four P12 Ulk4 $4^{\text {tm1a/tm1a }}$ and four $U l k 4^{+/+}$littermates were histologically investigated. Ventriculomegaly was evident in $U l k 4^{\text {tmla/tmla }}$ mice, with an LV size of $7.00 \pm 1.48 \mathrm{~mm}^{2}$ at the anterior commissural level, which was 17.5 -fold larger $(p<0.01)$ than that in WT littermates $(0.40 \pm$ $0.11 \mathrm{~mm}^{2}$; Fig. 2R). The Ulk $4^{\text {tmla/tmla }}$ third ventricle (3V; $0.122 \pm$ 

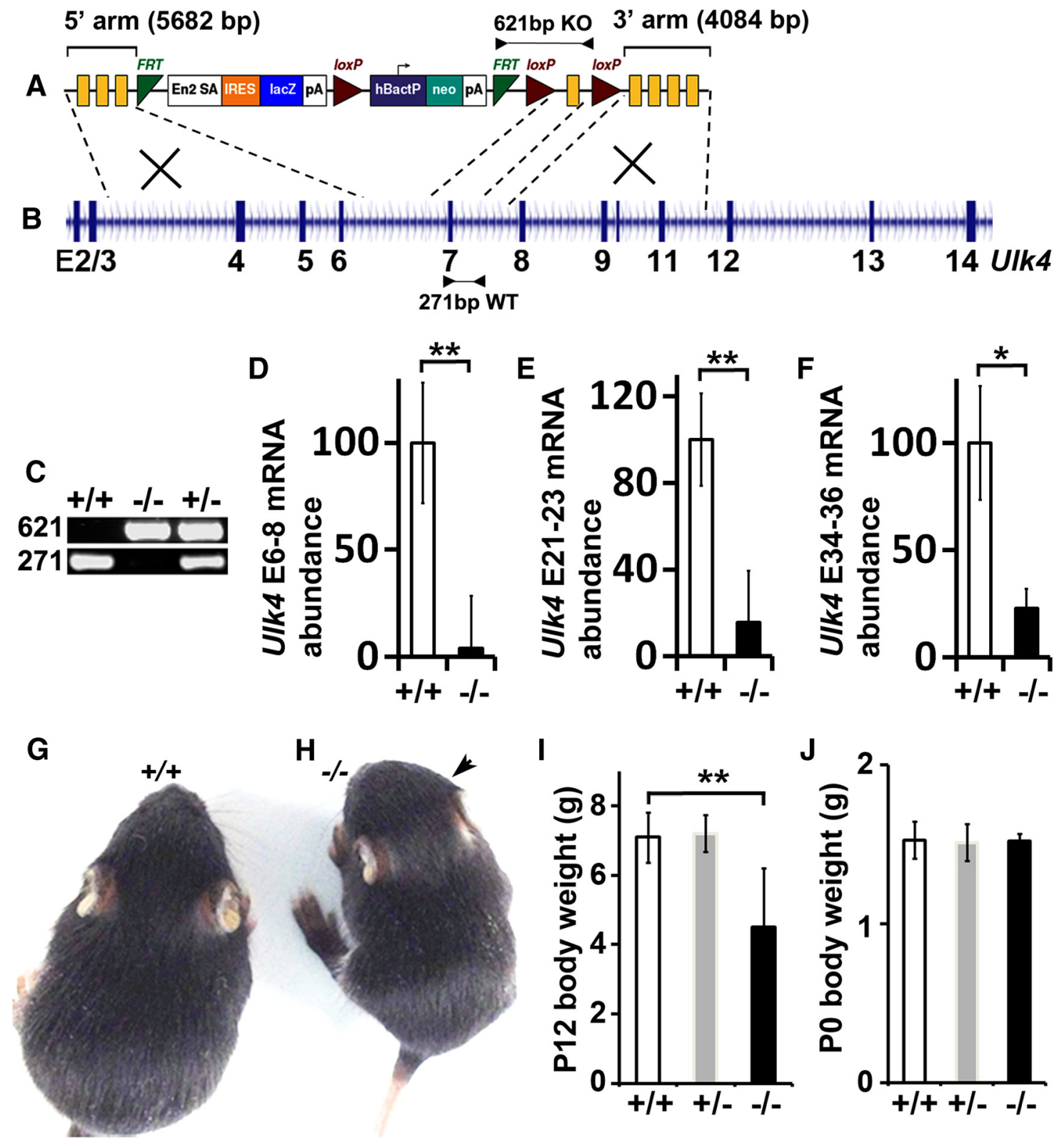

Figure 1. Ulk4 is essential for postnatal growth and survival. $A$, The Ulk4 knock-in construct harboring a cassette of FRT-En2SA-IRES-LacZ-PA-hBactP-Neo-PA-FRT-loxP-Exon7-IoxP. The 5' targeting arm was a 5682 bp fragment containing exons $4-6$ of $U / k 4$, and the 3 ' arm was a 4084 bp fragment containing exons $7-11$. Exon 7 was considered a critical exon flanked by two loxP sites. $B$, The mouse Ulk4 genomic organization. Arrowheads indicate the primer sequence location. C, For mouse genotyping, the targeted allele was identified by a 621 bp PCR band with Ulk4KOMPKOFor and Ulk4KOMPKORev. The WT allele was detected by $271 \mathrm{bp}$ PCR product with Ulk4E7For and Ulk4In7Rev. D-F, Ulk4 mRNA expression was assessed by qRT-PCR using primers derived from exon 6 - 8

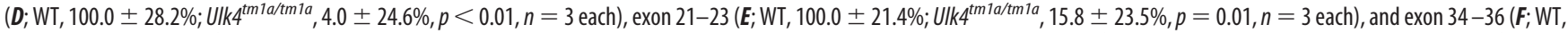

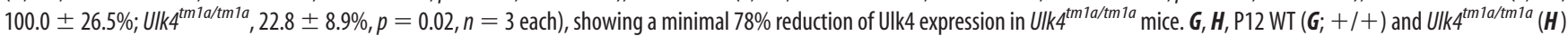
littermate mice with significantly reduced body size. The arrow in $\boldsymbol{H}$ highlights a domed-shaped head. $I$, The body weight of P12 (Ulk4 ${ }^{+/+}, n=12 ; U l k 4^{+/ t m 1 a}, n=12 ; U l k 4^{\text {tm } 1 a / t m 1 a}, n=5 ; p<$ $0.01)$ mice. $J$, The body weight of P0 mice $\left(U l k 4^{+/+}, n=8 ; U l k 4^{+/ t m 7 a}, n=9 ; U l k 4^{\text {tmla/tm7a }}, n=5\right)$ were quantified statistically, showing no significant difference. $+/+$, WT Ulk4 ${ }^{+/+} ;+/-$, heterozygote Ulk4 $4^{+/ t m 1 a} ;-1-$, homozygote Ulk4tm1a/tm1a; $* * 00.01$.

$0.070 \mathrm{~mm}^{2}$; Fig. $2 \mathrm{H}, \mathrm{S}$ ) was also 4.7 -fold dilated (Fig. $2 \mathrm{H} ; \mathrm{p}=$ $0.03)$ compared with that of the controls $\left(0.026 \pm 0.003 \mathrm{~mm}^{2}\right.$; Fig. $2 G)$.

The SCO is important for CSF flow, and the relationship between abnormal SCO and hydrocephalus has been well documented in animals (Lee et al., 2012). We quantified the number of SCO cells and found no significant difference between $U l k 4^{\text {tmla/tmla }}$ and WT mice (Fig. $2 I, J, T ; p=0.67$ ). However, the ventricle at the posterior commissural level was fivefold dilated in $U l k 4^{\text {tmla/tmla }}$ mice (Fig. 2 I, J,U; $p<0.05$ ). The SCO generates and secretes Reissner's fiber (RF) into the CSF, which extends cau- dally to the aqueduct, fourth ventricle $(4 \mathrm{~V})$, and spinal cord. Impaired RF production/secretion can lead to aqueduct stenosis, causing obstructive hydrocephalus (McAllister, 2012). Whereas the RF was apparent in WT littermates (Fig. 2I, arrow), we failed

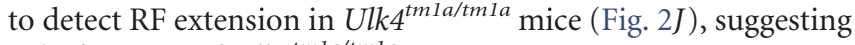
a dysfunction of $U l k 4^{\text {tmla/tmla }}$ SCO.

The aqueduct is a narrow channel connecting the $3 \mathrm{~V}$ and $4 \mathrm{~V}$. Remarkably, in Ulk4 $4^{\text {tmla/tmla }}$ mice, the aqueduct was not overtly dilated (Fig. $2 L, K$ ). Scanning electron microscopy revealed aqueduct blockage in the mutants (Fig. $2 N, P$ ), which was not seen in the WT aqueduct (Fig. $2 \mathrm{M}, \mathrm{O}$ ). These data demonstrate that 

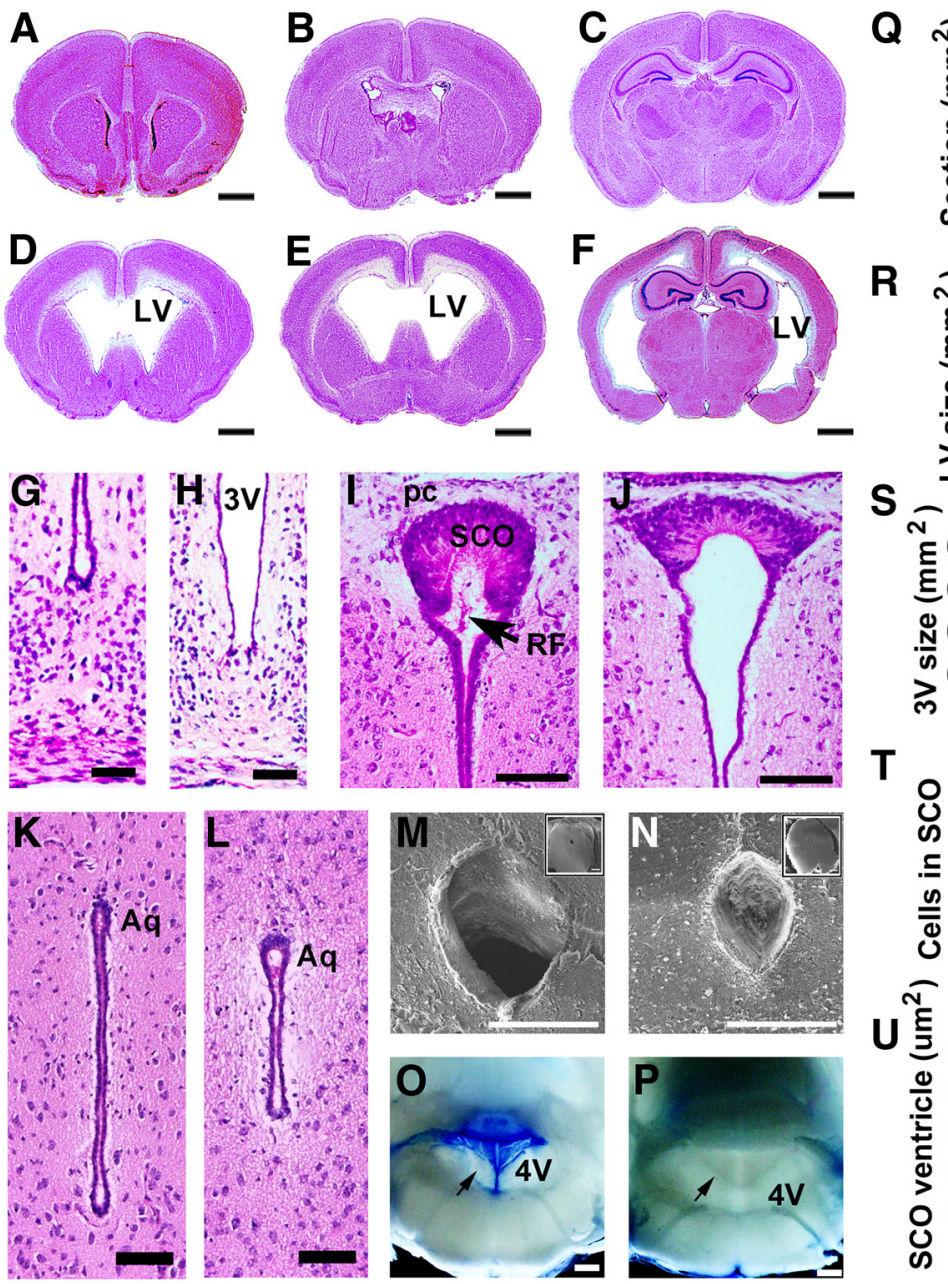

$\mathrm{S}$

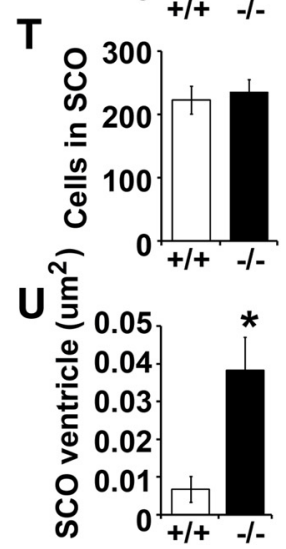

Figure 2. Ulk4 ${ }^{t m 1 a / t m 1 a}$ mice display hydrocephalus phenotype at P12. A-L, H\&E-stained brain sections of WT littermate mice $(\boldsymbol{A}-\boldsymbol{C}, \boldsymbol{G}, \boldsymbol{I}, \boldsymbol{K})$ and P12 Ulk4 ${ }^{\text {tm1a/tm1a }}$ brain sections $(\boldsymbol{D}-\boldsymbol{F}, \boldsymbol{H}, \boldsymbol{J}, \boldsymbol{L}) . \boldsymbol{M}, \boldsymbol{N}$, Scanning electron microscopy images of WT $(\boldsymbol{M})$ and Ulk4 $4^{\text {tm 1a/tm1a }}(\boldsymbol{N})$ aqueduct, showing aqueductal blockage in the mutant $(\boldsymbol{N}) . \mathbf{O}, \boldsymbol{P}$, Images of brain slice at the 4V (arrow) from WT $(\boldsymbol{O})$ and mutant $(\boldsymbol{P})$ mice. $\mathbf{Q}-\boldsymbol{U}$, Statistical quantifications show significantly enlarged $L V(\boldsymbol{R}), 3 V(\boldsymbol{S})$, and SCO ventricles $(\boldsymbol{U})$. Scale bars: $\boldsymbol{A}-\boldsymbol{F}, 1 \mathrm{~mm} ; \boldsymbol{G}-\boldsymbol{J}, 50 \mu \mathrm{m} ; \boldsymbol{K}, \boldsymbol{L}, 100 \mu \mathrm{m} ; \boldsymbol{M}, \boldsymbol{N}$, insets, $500 \mu \mathrm{m} ; \boldsymbol{M}-\boldsymbol{P}, 200 \mu \mathrm{m} .{ }^{*} p<0.05 ;{ }^{* *} p<0.01$. Aq, Aqueduct; LV, lateral ventricle; $p c$, posterior commissure; RF, Reissner's fiber; SCO, subcommissural organ; $+/+, U l k 4^{+/+} ;-/-$, Ulk4 $4^{\text {tm 1a/tm1a }}$.

Ulk $4^{\text {tmla/tm1a }}$ hydrocephalus was associated with SCO dysfunction and aqueduct stenosis.

\section{The hydrocephalus phenotype is present in P0 \\ Ulk $4^{\text {tmla/tmla }}$ mice}

Congenital hydrocephalus accounts for $\sim 55 \%$ of all hydrocephalus (Carter et al., 2012). To determine the nature of Ulk4 ${ }^{\text {tm la/tmla }}$ hydrocephalus, we histologically analyzed $U l k 4^{\text {tm1a/tm1a }}$ brains and littermate controls at P0, when Ulk $4^{\text {tmla/tmla }}$ mice did not show gross abnormality. A significant dilation of the LV and $3 \mathrm{~V}$ was detected (Fig. 3). However, the enlargement at P0 (Fig. 3E; 5.0-fold) was not as dramatic as at P12 (Fig. 2R; 17.5-fold). These results showed that $U l k 4^{\text {tmla/tmla }}$ hydrocephalus was congenital, but the phenotype was progressively worsened during the early postnatal period, which coincided with the development and maturation of ependymal cilia.

\section{CSF flow is obstructed in the $U l k 4^{\text {tm 1a/tmla }}$ aqueduct}

CSF flows sequentially from the LV to the $3 \mathrm{~V}$, aqueduct, and $4 \mathrm{~V}$, before entering the subarachnoid space and draining into the blood primarily through arachnoid granulations. Ciliary beating
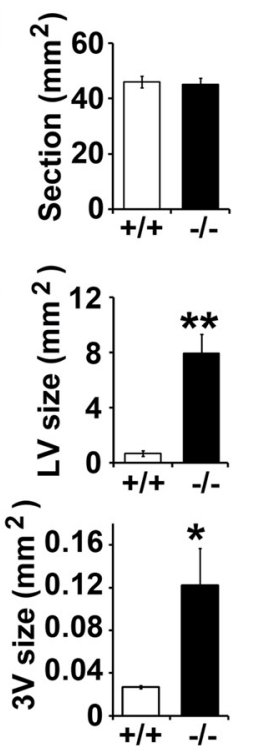

and CSF flow may be visualized on brain slices in vitro (Sawamoto et al., 2006). Aqueduct obstruction is common in animal models. Evans blue is an azo dye that binds with high affinity to serum albumin, flows with the CSF, and is also used to trace CSF flow in animals (Kim et al., 2012).

We investigated CSF flow with Evans blue in three P12 Ulk $4^{\text {tmla/tmla }}$ mice and four WT littermate controls by injecting 5 $\mu l$ of the dye (4\% in PBS) into the LV (Fig. 4 ). The mice were kept in anesthetized status for $20 \mathrm{~min}$ to permit the dye to flow with CSF in vivo. Mice were then terminated and examined for dye distribution. The dye was detected throughout all ventricles in WT littermates (Fig. 4, top, W1W4; $n=4$ ), including the LV (Fig. 4, A), 3V (Fig. 4, B), SCO (Fig. 4, $C$ ), aqueduct (Fig. $4 \mathrm{D}, \mathrm{Aq}$ ), 4V (Fig. 4, E), and spinal canal (Fig. 4, F, SC).

In contrast to well restrained dye distribution in the WT littermates from the LV to the spinal canal, there was little evidence of CSF flow in Ulk $4^{\text {tmla/tmla }}$ brains $(n=3$; Fig. 4). The dye was detected in the LV (Fig. 4, A, M1-M3) and 3V (Fig. 4, B). However, little dye reached the SCO ventricle (Fig. 4, C), and no dye was seen in the Ulk $4^{\text {tm la/tmla }}$ aqueduct (Fig. 4, D), $4 \mathrm{~V}$ (Fig. 4, E) or spinal canal (Fig. 4, F, SC). These data consistently demonstrated that the injected Evans blue was passively diffused from the $\mathrm{LV}$ to the $3 \mathrm{~V}$ in $U l k 4^{\text {tmla/tmla }}$ mice. Ulk4 deficiency therefore functionally impairs the CSF circulation, leading to hydrocephalus in the mutants.

\section{Ulk4 is predominantly expressed in the ventricular system}

The impaired CSF flow suggested a failure of ependymal function in five Ulk $4^{\text {tmla/tm1a }}$ male mice. To explore pathological mechanisms of $U l k 4^{\text {tmla/tmla }}$ hydrocephalus, we first investigated the expression pattern of Ulk4 in mice (Fig. 5). The Ulk4 $4^{\text {tm la/tmla }}$ mice were created by replacing exon 7 of Ulk4 with an IRES-lac $Z$ reporter (Fig. $1 A, B$ ). Therefore an Ulk4-IRES-lacZ fusion mRNA was anticipated to be transcribed from the Ulk4 promoter. We stained P14 brain sections with X-gal and observed weak $\beta$-gal activity in the choroid plexus, where the CSF was produced (Fig. $5 A, \mathrm{CP}$ ), and in the subfornical organ (Fig. 5C, SFO), which has been reported to be involved in hydrocephalus.

The most intense lacZ staining was detected in the ventricular system, including ependymal cells in the LV, 3V, SCO, and aqueduct (Aq; Fig. 5B-F). Notably, Ulk4 was highly expressed in the lateral wall of the aqueduct with motile cilia (Fig. 5F, arrowheads), but not on the roof of the aqueduct, which was occupied by nonciliated cells (Collins, 1983). The predominant Ulk4 expression in mature ependymal cells suggests that Ulk4 plays a vital role in CSF circulation. 


\section{$U l k 4^{\text {tm1a/tm1a }}$ mice display impaired motile cilia}

CSF circulation is largely considered unidirectional, and directional flow is driven by coordinated beating of ependymal cilia. To investigate ciliary development, we first immunohistochemically stained P12 brains with antiacetylated $\alpha$-tubulin, a ciliary marker, when motile cilia were fully developed and matured. Highly organized cilium bundles were found to be arrayed in a linear fashion on the WT ependymal wall (Fig. 5G, arrowhead). In contrast, Ulk $4^{\text {tmla/tmla }}$ cells exhibited disorganized and less dense cilia (Fig. $5 \mathrm{H}$, arrowhead), or absence of cilia (Fig. $5 \mathrm{H}$, arrow). However, the cilia length appeared comparable (Fig. 5G-J).

We subsequently performed scanning electron microscopy to examine the LV surface (Fig. 5I,J). On the Ulk4 ${ }^{+/ t m l a} \mathrm{LV}$ wall, the ependymal cilia were organized into bundles and orientated in the same direction (Fig. 5I), indicative of coordinated/directional beating. In the Ulk $4^{\text {tmla/tm1a }}$ mice, the number of cilia bundles was dramatically reduced (Fig. 5J), and a large proportion of cells did not have cilia arrays, suggestive of underdevelopment of motile cilia. The Ulk $4^{\text {tmla/tm1a }}$ cilia were highly disorganized and randomly scattered on the surface of the ependymal wall, a sign of dysfunctional cilia with no directional beating (Fig. $5 J$ ).

\section{$U l k 4^{\text {tm 1a/tm1a }}$ mice display major defects in basal body}

\section{orientation and axonemal organization}

During ciliogenesis, the basel bodies (BBs) from centrioles migrate toward the surface of the cell. Along the way, the BBs attach to membrane vesicles and form a BB-vesicle complex. The vesicle membrane in the complex fuses with the plasma membrane, and axonemal microtubules then extend from the BB. To investigate the underlying mechanism of disorganized cilia in Ulk4 $4^{\text {tmla/tmla }}$ mice, we examined the BB position, which determines the cilium orientation. In WT ependymal cells, multicilia were fully developed, matured, clustered, and oriented in a same direction (Fig. $6 A, D$ ). In line with this, all $B B s$ were aligned in parallel and leaned in the same direction (Fig. 6A,D, arrows).

The length of the Ulk $4^{\text {tm 1a/tmla }}$ cilia (Fig. $6 A$, ) was not markedly shortened. However, fewer cilia or the absence of cilia were observed on Ulk4 $4^{\text {tmla/tmla }}$ ependymal cells. Instead, microvilli of smaller and shorter projections abundantly occupied the $U l k 4^{\text {tmla/tmla }}$ ependymal cell surface (Fig. 6B,C,E,F, MV). The cilia development appeared delayed also in the Ulk4 ${ }^{\text {tmla/tm1a }}$ mice, as the BB-vesicle complex was still present beneath the P18 $U l k 4^{\text {tmla/tmla }}$ ependymal membrane (Fig. 6B,F, black box). Dispersed and randomly orientated BBs were present in Ulk $4^{\text {tmla/tmla }}$ mice (Fig. 6B, $C, E, F$ ). Some adjacent BBs were oriented in completely different directions, and this was evident from the appearance of cross-sectional view of BB feet (Fig. 6E, black box). $\mathrm{BB}$-vesicle fusion complexes with $90^{\circ}$ difference to the normal orientation were also detected in $U l k 4^{\text {tmla/tmla }}$ ependymal cells (Fig. 6F). Collectively these data point to the delayed cilia development and misalignment of BBs in Ulk $4^{\text {tmla/tmla }}$ mice.
Motile cilia have a basic axonemal structure with nine peripheral doublets and a central pair of microtubules, termed $9+2$, which is different from primary cilia lacking the central pair $(9+$ $0)$. To further investigate effects of Ulk4 on microtubular ultrastructure of ependymal cilia, we performed transmission electron microscopy on P18 mice. In WT mice, all axonemes exhibited typical $9+2$ ultrastructure across sections (Fig. 6G). In Ulk $4^{\text {tmla/tmla }}$ mice, some exhibited normal structure (Fig. $6 H$ ), whereas others showed various defects in axonemes, i.e., missing the central doublets $(9+0$; Fig. $6 I)$, with a disorganized peripheral doublet also lacking the central pair (also $9+0$; Fig. $6 J$ ), losing a peripheral doublet but gaining a supernumerary central pair $(8+4$; Fig. $6 K)$, or missing the central and a peripheral doublets $(8+0$; Fig. $6 L)$. Together, these data showed that $U l k 4^{\text {tmla/tmla }}$ ependymal cilia were underdeveloped, disorganized, structurally disassembled, and functionally impaired.

\section{Ulk4 deficiency dysregulates Foxj1 and other ciliogenesis molecules}

Ulk4 is a relatively novel Ser/Thr kinase and nothing is known about it at the molecular level. To understand molecular mechanisms of cilium dysfunction in Ulk $4^{\text {tmla/tmla }}$ mice, we performed whole-genome RNA sequencing and obtained quantitative reads from 19,652 genes in three Ulk $4^{\text {tmla/tmla }}$ and three WT controls. Relative mRNA abundance was quantified, normalized, and expressed in FPKM. The data were analyzed by multiple testing, FDR, log2 ratio (knock-out/WT), mean, SEM, and one-way ANOVA, which identified 1824 genes significantly $(p<0.05)$ upregulated and 1005 genes significantly downregulated in P12 Ulk $4^{\text {tm 1a/tm1a }}$ cortices.

We first compared expression of three master regulators of ciliogenesis, Foxj1, $R f x 3$, and Mcidas. None of the $8 R f x$ family members $(R f x 1-8, p>0.05)$ nor Mcidas (30\% reduced, $p=0.10$ ) was significantly altered in $U l k 4^{\text {tmla/tmla }}$ mice (Fig. $7 A, C$ ). However, the expression of Foxj1 and Foxj3 increased by 1.59-fold $(p=0.03)$ and 1.33 -fold $(p=0.04)$, respectively (Fig. $7 A)$, sug- 


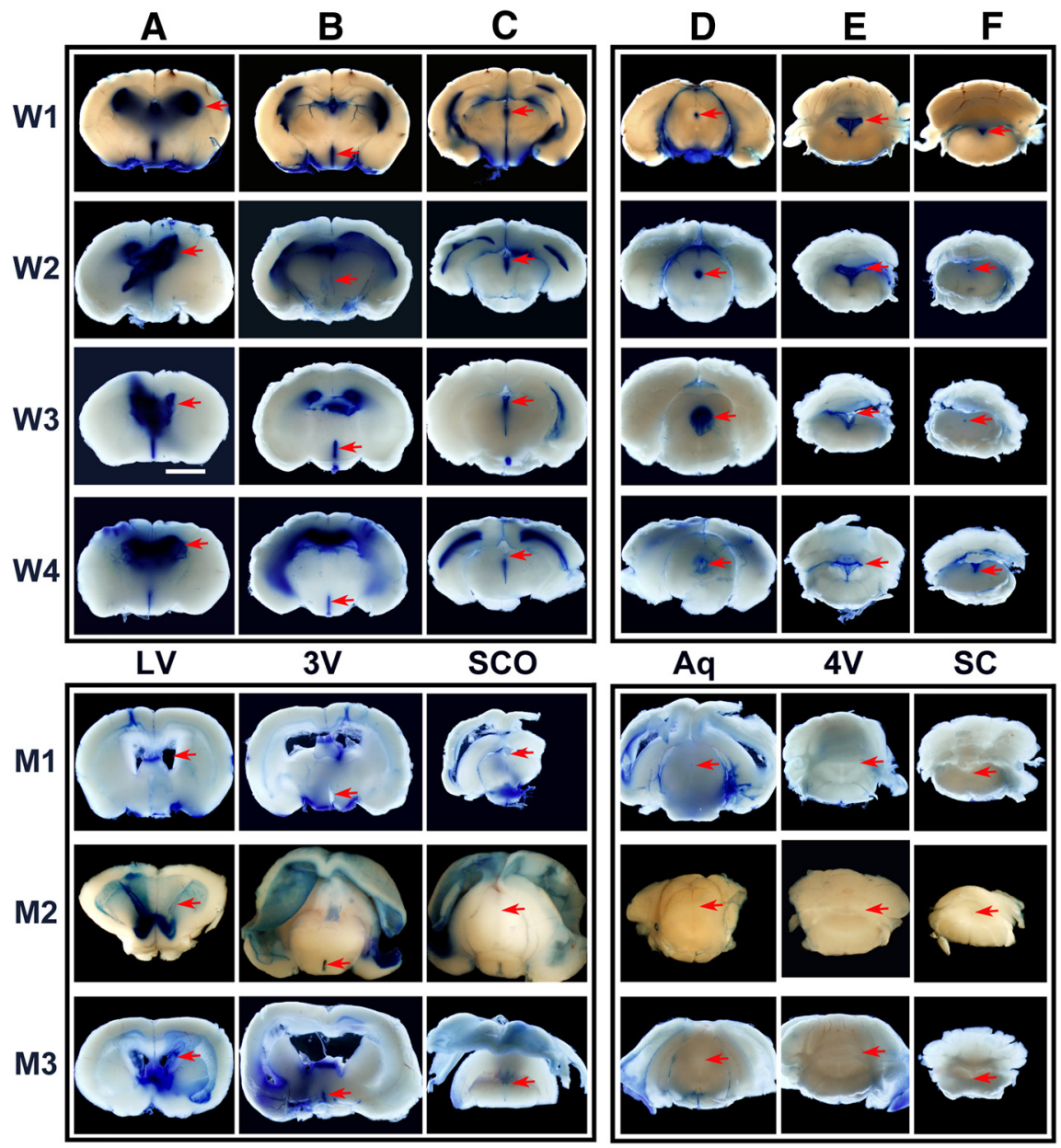

Figure 4. Impaired CSF circulation in Ulk4 ${ }^{\text {tm 1a/tm1a }}$ mouse brain. Four P12 WT (W1-W4) and three mutant (M1-M3) mice were intraventricularly injected with $5 \mu$ l of Evans blue dye into the dorsal cortex (4\% in PBS). The dye was allowed to flow with the CSF in vivo for $20 \mathrm{~min}$. Mouse brains were subsequently fixed, sectioned, and imaged at the comparable levels of $L V(\boldsymbol{A}), 3 \mathrm{~V}(\boldsymbol{B}), \operatorname{SCO}(\boldsymbol{C})$, aqueduct $(A q ; D), 4 V(E)$, and spinal canal $(S C ; F)$. Arrows indicate the anatomical positions of the LV, 3V, SCO, Aq, 4V, and SC of WT littermate and UIk4 ${ }^{t m 1 a / t m 1 a}$ mutant brains. Note that in the WT brains, the dye flowed from the LV to SC with defined localization in the ventricles (W1-W4, $\boldsymbol{A}-\boldsymbol{F}$ ). In three mutants, the dye was largely diffused from $\mathrm{LV}$ to $3 \mathrm{~V}$ passively, with little dye reaching the SCO and no dye reaching the $\mathrm{Aq}, 4 \mathrm{~V}$, or SC of the Ulk $4^{\mathrm{tm} 1 a / \mathrm{tm} 1 a}$ brain (D-F, bottom right), demonstrating an impaired CSF flow in

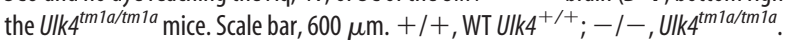

gesting a specific effect on the Foxj1 pathway in Ulk4 $4^{\text {tmla/tmla }}$ mice. Though no current literature suggests the involvement of Foxj3 in ciliogenesis, Foxj1 is overwhelmingly shown as a master switch that controls a series of ciliogenesis genes (Yu et al., 2008; Thomas et al., 2010; Choksi et al., 2014). We next pulled out 414 cilia-related genes from 19,652 transcripts and compared their expression levels, and identified 66 genes $(15.94 \%, p<0.05)$ that were significantly altered, with 18 downregulated and 48 upregulated. The bioinformatic analyses by the STRING database gave rise to a ciliary pathway with a $p$ value of $1.949 \times 10^{-35}$.

Ciliogensis is a complicated and precisely controlled process, and amplification of tens to hundreds of centrioles is an initiation step. Gsn, Tmem67, Katnb1, Asap1, Ptpn23, Poc1b, Ccdc78, Poc5, Cep120, Cep152, and Plk4 have been implicated in centriole amplification (Arts et al., 2007; Lee and Gleeson, 2011). Among them, Gsn was $40 \%$ downregulated ( $p=0.03$; Fig. $7 E$ ), and Poc1b $20 \%$ reduced $(p=0.07)$. On the other hand, Tmem67 $(1.28$-fold, $p=0.01)$, Poc5 (1.27-fold, $p=0.037)$, Cep120 (1.19-fold, $p=$ $0.04)$, and Cep152 (1.26-fold, $p<0.05)$ were significantly upregulated (Fig. $7 E$ ). The ependymal cilia should be fully matured at the time of analysis. Increased expression of procentriole com- ponents (Cep152, Cep120, and Poc5) in P12 Ulk4 $4^{\text {tmla/tmla }}$ cortex also suggested a delay of ciliogenesis in $U l k 4^{\text {tmla/tmla }}$ mice.

Transmission electron microscopy analyses showed misalignment of BBs in the Ulk $4^{\text {tmla/tmla }}$ ependymal cells. We next examined genes Odf2, Nphp4, Tmem67, Vangl1, Pcm1, Nedd1, Celsr2, and Celsr3, which were shown to regulate $\mathrm{BB}$ orientation (Ansley et al., 2003; Arts et al., 2007; Manning et al., 2008; Tissir et al., 2010; Kunimoto et al., 2012; Vladar et al., 2012; Leightner et al., 2013). Whereas expression of Odf2 (1.11-fold, $p<0.05)$, Nphp4 (1.43-fold, $p=0.02)$, and Tmem67 (1.28fold, $p=0.01)$ increased, Vangl1 was significantly downregulated in $U l k 4^{\text {tmla/tmla }}$ mice $(33 \%, p=0.02$; Fig. $7 B)$, which is consistent with a previous report that cilia were randomly positioned in Vangl1 ${ }^{-1-}$ / Vangl2 ${ }^{-1-}$ mice (Song et al., 2010).

A centriolar satellite component, PCM1, was mutated in a family with ciliary defects and body-axis asymmetry (Ansley et al., 2003), and shown to colocalize and interact with BBS8 in centrosomes and BBs. Pcm1 increased 19\% in $U l k 4^{\text {tmla/tmla }}$ mice $(p=0.01$; Fig. $7 B)$. On the other hand, Nedd1, a key component of the BB localized at the root of ciliated microtubules (Manning et al., 2008), was $30 \%$ reduced $(p=0.03$; Fig. $7 B)$. Gsn also regulates the cilia number by severing actin filaments (Kim et al., 2010), and the expression of $G s n$ was decreased by $40 \%$ in $U l k 4^{\text {tmla/tmla }}$ mice $(p=0.03$, Fig. $7 E)$.

The transmission electron microscopy data also revealed defects in axonemal assembly of microtubular doublets. Microtubules are heterodimers of $\alpha$-tubulins and $\beta$-tubulins, and Tubb4a is the predominant subtype in the brain, which represents $46 \%$ of all $\beta$-tubulins (Leandro-Garcia et al., 2010). In $U l k 4^{\text {tmla/tmla }}$ mice, Tubb4a was $16 \%$ reduced ( $p<0.01$; Fig. $\left.7 D\right)$. Spag6, Rsph4a, Rsph9, and Rsph1 encode central pair components (Lee et al., 2012). RNA sequencing data showed that Foxj1 and three targets, Spag6 (1.46-fold, $p<0.001$ ), Rsph4a (1.75-fold, $p<$ 0.01 ), and Rsph9 (1.31-fold, $p<0.01$ ), were significantly upregulated. Dnah9 and Dnall encode axonemal dynein heavy chain 9 and dynein light chain 1, respectively, as key components of the outer dyneins arm. Interestingly, the low-abundance gene Dnah 9 was 2.1 -fold increased ( $p<0.01$; Fig. $7 D)$, whereas highly abundant Dnal1 was $10 \%$ reduced in the Ulk $4^{\text {tmla/tmla }}$ brain $(p=0.04$, Fig. $7 F$ )

CSF flow was impaired in Ulk $4^{\text {tmla/tmla }}$ mice and we next analyzed Odf2, Spag6, Lgals3, Tekt2, Dnah10, Dnal1, Ttll6, and Drc1, which were known to be involved in cilia beating (Fig. 7F; Mitchell et al., 2007; Suryavanshi et al., 2010; Mazor et al., 2011; Kunimoto et al., 2012; Clare et al., 2014). Four of them, Spag6 (1.46-fold, $p<0.01)$, Tekt2 (1.38-fold, $p=0.03)$, Odf2 (1.11fold, $p=0.05)$, Lgals3 (7.48-fold, $p<0.01$ ), and related Lgals3bp (1.59-fold, $p<0.01)$, were significantly upregulated. In contrast, Ttll6, encoding a tubulin tyrosine ligase, was $49 \%$ reduced $(~ p=$ 
0.06). Kif5a encodes a member of the kinesin family and functions as a microtubule motor. Clustering of kinesin-1 was shown to cause cilia-like beating of active microtubule bundles (31). In consistent with impaired CSF flow in Ulk $4^{\text {tmla/tmla }}$ mice, Kif5a expression was 19\% reduced $(p<0.01$; Fig. $7 F)$.

Analyses of the RNA expression (FPKM) by $\log 2$ ratio, multiple testing $(p<0.05)$, and FDR $(<0.01)$ confirmed significant changes of Foxj1, Pcm1, Tubb4a, Dnah9, Rsph4a, Gsn, Kif5a, Lgals3, Lgals3bp, and Dnal1 genes in Ulk4 $4^{\text {tm la/tmla }}$ mice. Together, these data showed that Ulk4 deficiency disturbed expression of the Foxj1 gene and a series of ciliogenesis genes, which consequently compromised ciliary development, axonema structure, coordinated beating, and CSF flow, which resulted in hydrocephalus in $U l k 4^{\text {tmla/tm1a }}$ mice.

\section{Discussion}

Ciliopathies are pathogenic features of numerous human diseases, including hydrocephalus. Here we characterized the hypomorph Ulk4 $4^{\text {tmla/tm1a }}$ mutant mouse strain with $4-22 \%$ of Ulk4 mRNA expressed. Ulk4 $4^{\text {tmla/tmla }}$ mice showed congenital hydrocephalus, which became severer postnatally with impaired CSF flow. The mutants displayed reduced/disorganized/nonfunctional ependymal cilia with defective axonemes. RNA sequencing analyses uncovered dysregulation of Foxj1 and other ciliogenesis genes, and the majority of them are interconnected by the STRING analysis (Fig. $7 H$ ). Therefore, Ulk4 is likely to act as an essential scaffold protein regulating ciliogenesis.

The Ulk4 family consists of five members. Ulk1 and Ulk2 are major regulators of autophagy (Egan et al., 2011; Lee and Tournier, 2011), whereas Ulk3 is involved in Shh signaling (Fuccillo et al., 2006). We previously reported the role of ULK4 in neuritogenesis, and ULK4 deficiency compromised neurite outgrowth in neuroblastoma cells and corpus callosum integrity in mice (Lang et al., 2014). Stk36 deficiency causes hydrocephalus in mice (Merchant et al., 2005), and this is confirmed by Lexicon Pharmaceuticals through screening of 4650 mouse models, which identify Stk36 and Ulk4 as risk factors among Ak7, Ak8, Celsr2, Dpcd, FZD3, Kif27, Mboat7, Nme5, Nme7, and RIKEN 4930444A02 genes. However, the pathological details or molecular mechanisms of these mutations remain elusive (Vogel et al., 2012). We show that neither Stk36 nor other family members is compensated for the Ulk4 hypomorph. Therefore both Ulk4 and Stk36 are indispensable for proper CSF circulation.

Ulk4 hydrocephaly is congenital as mild neuropathology appears at birth, which is worsened postnatally with aqueduct stenosis, dysfunctional SCO, and, more importantly, defective motile cilia. SCO cells secrete high-molecular-weight glycoproteins to maintain aqueduct patency. Impaired RF production/ secretion can lead to obstructive hydrocephalus (McAllister, 2012), and abnormal RF and SCO dysplasia are associated with obstructive hydrocephalus in Sox3-overexpressing mice (Lee et al., 2012). Ulk4 protein colocalizes with Sox3 (Domínguez et al., $2015)$, but Sox3 expression $(87 \%, p=0.34)$ is not significantly altered in $U l k 4^{\text {tmla/tmla }}$ mice.

The characteristic feature of hydrocephalus is the ventricular dilation with excessive CSF. The Evans blue injection demonstrates no directional CSF flow, but passive diffusion in the $U l k 4^{\text {tmla/tmla }}$ brain. Directional CSF flow requires ependymal motile cilia, which are developed within the first postnatal week and coincide with progressive severity of the Ulk $4^{\text {tmla/tmla }}$ phe- 

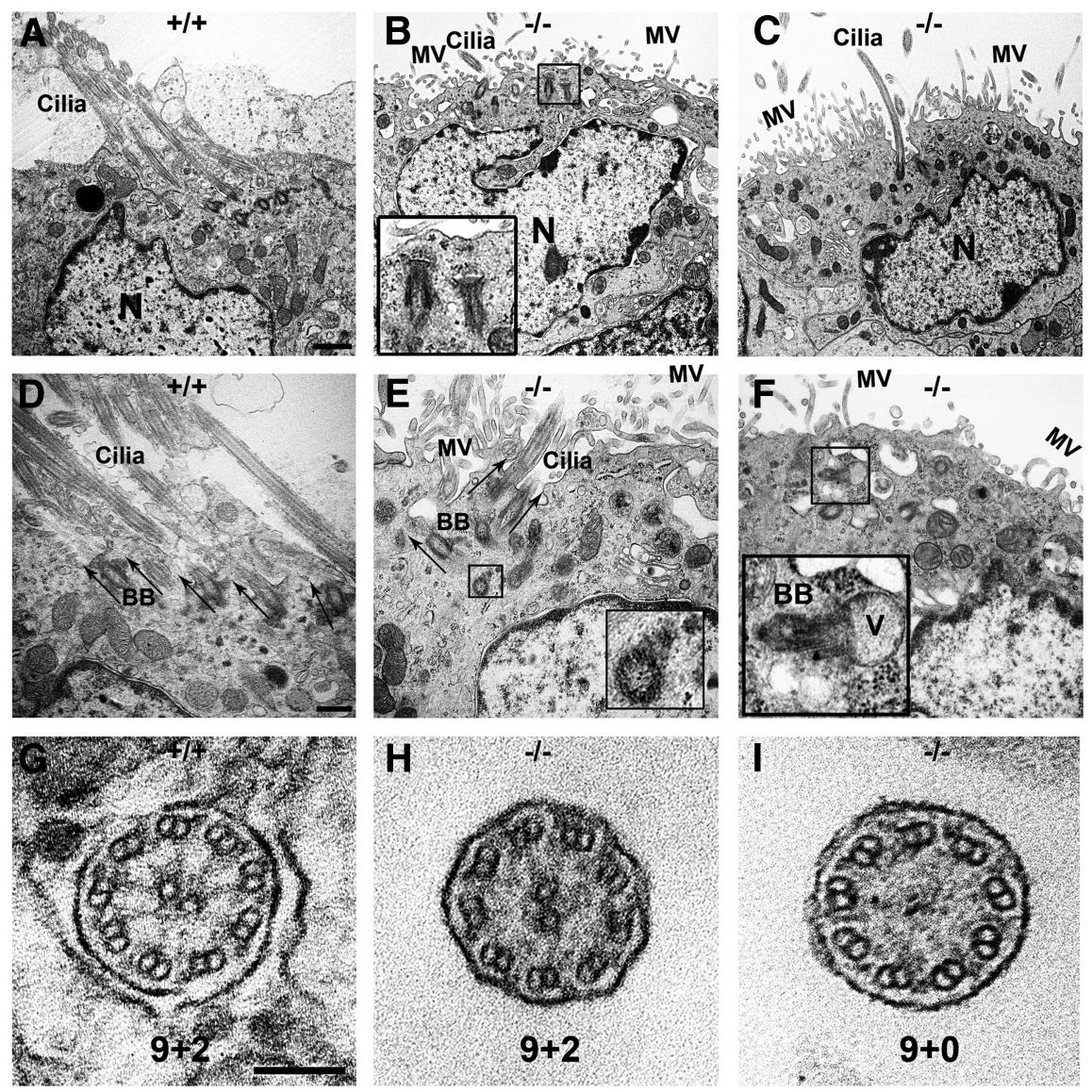
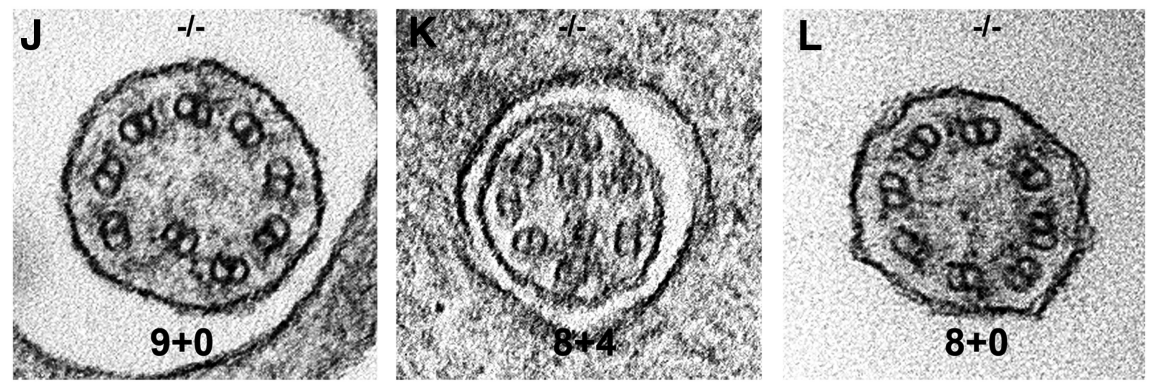

Figure 6. Ulk4 deficiency impairs axonemal structure and ciliary function. $\boldsymbol{A}-\boldsymbol{F}$, Transmission electron microscopic images of radial sections of ependymal cells. Clusters of multicilia with the same orientation appeared on P18 WT ependymal cells $(\boldsymbol{A}, \boldsymbol{D}$, arrows), but reduced $(\boldsymbol{B}, \boldsymbol{C}, \boldsymbol{E})$ or absent $(\boldsymbol{F})$ in Ulk $4^{\text {tm } 1 a / t m 7 a}$ cells $(\boldsymbol{B}, \boldsymbol{C}, \boldsymbol{E}, \boldsymbol{F})$. The black boxes in $\boldsymbol{B}$ and $\boldsymbol{F}$ show an immature cilium, namely a BB-vesicle fusion complex, beneath the Ulk $4^{\text {tm1a/tm1a }}$ cell membrane. Cilium length was not shortened in the Ulk $4^{\text {tm1a/tm1a }}$ mice $(A, C-E)$, but the BB orientation was dispersed in the Ulk $4^{\text {tm } 7 a / t m 7 a}$ cells $(A, D)$. Arrows show normally embedded BBs in WT $(D)$, but

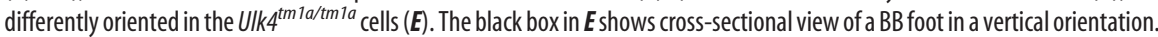
The black box in $\boldsymbol{F}$ shows a BB-vesicle fusion complex oriented parallel to the ependymal membrane, which varies by $90^{\circ}$ from the normal orientation. $\mathbf{G}$, WT littermates presented normal axonemes of $9+2$. $\boldsymbol{H}-\boldsymbol{L}$, Some $U / k^{4 t m 1 a / t m 1 a}$ motile cilia exhibited $9+$ $2(\boldsymbol{H})$, but others either lost the central doublets without $(9+0 ; \boldsymbol{I})$ or with disorganization of a peripheral doublet (also $9+0 ; \boldsymbol{J})$, or missed a peripheral doublet but had a supernumerary central doublet $(8+4 ; \boldsymbol{K})$, or lost peripheral and central doublets $(8+$ $0 ; \boldsymbol{L})$. Scale bars: $\boldsymbol{A}-\boldsymbol{C}, 1000 \mathrm{~nm} ; \boldsymbol{D}-\boldsymbol{F}, 500 \mathrm{~nm} ; \boldsymbol{G}-\boldsymbol{L}, 100 \mathrm{~nm}$. Insets in $\boldsymbol{B}, \boldsymbol{E}$, and $\boldsymbol{F}$ were magnified three times from the respective images. MV, Microvilli; $\mathrm{N}$, nucleus; V, vesicle; $+/+, U l k 4^{+/+} ;-/-, U l k 4^{\text {tm } 1 a / t m 7 a}$.

notype. Ulk4 is highly expressed in ependymal cells, SCO, and aqueducts consisting of multiciliated cells, but not on the roof of the aqueduct which is populated by nonciliated cells, highlighting the importance of Ulk4 for motile cilia.

The coordinated/directional ciliary beating from multiple ependymal cells produces stereotypical CSF flow (Breunig et al., 2010), and abnormal cilia are associated with hydrocephalus in patients (Fliegauf et al., 2007; Lee and Gleeson, 2011) and in mice with Foxj1, Ro1, Polaris/Ift188, Mdnah5, Hydin, or Spag6 muta- tion (Huh et al., 2009). We first observe abnormal and disorganized cilia in Ulk4 mice by anti- $\alpha$-tubulin staining, which is supported by scanning and transmission electron microscopy data. Many Ulk $4^{\text {tm Ial }}$ tmı ependymal cells lack motile cilia, and mutant cilia are highly disorganized and randomly scattered, display no consistent orientation, and are strikingly different from uniformly oriented and tightly clustered cilia, which are signs of coordinated beating, in WT littermates. The transmission electron microscopy reveals fewer cilia and misaligned BBs, subcellular mechanisms for disorganized cilia bundles. The $9+2$ microtubular ultrastructure is the distinguishing feature of motile cilia. The central pair is crucial for beating. However, Ulk $4^{\text {tmla/tmla }}$ axonemes exhibit an array of $9+0,8+4$, and $8+0$ ultrastructures. Together, these data show the fundamental importance of Ulk4 in ciliary development and function.

Ulk4 is a hypothetical kinase and nothing is known about its substrates or interactive partners. Other family members possess a conserved lysine at $\mathrm{ULK1} 1^{\mathrm{K} 46}$, $\mathrm{ULK} 2{ }^{\mathrm{K} 39}$, ULK3 ${ }^{\mathrm{K} 26}$, and STK $36^{\mathrm{K} 33}$, whereas the respective residue 33 in Ulk4 is leucine. Mutations of $\mathrm{ULK} 1^{\mathrm{K} 46 \mathrm{~N}}$ or $\mathrm{ULK} 2{ }^{\mathrm{K} 39 \mathrm{~T}}$ dominantly inactivate the kinase activity (Chan et al., 2009). It would be interesting to determine ULK4 kinase activity.

In the absence of known Ulk4 substrates or binding partners, we performed whole-genome sequencing and identified dysregulated genes. While Foxj1 was specifically altered in the Ulk $4^{\text {tmla/tmla }}$ brain, $R f x 3$ and Mcidas, two other master genes of ciliogenesis, were not (Yu et al., 2008; El Zein et al., 2009; Thomas et al., 2010; Choksi et al., 2014). This is the first evidence suggesting that elevated Foxj1 signaling may also be pathogenic to the ciliogenesis and function. Consistent with Foxj1 upregulation, a whole array of ciliogenesis genes were modulated in $U l k 4^{\text {tmla/tmla }}$ mice. For example, among genes involved in centriole amplification (Keller et al., 2009; Al Jord et al., 2014), Tmem67, Poc5, Cep120, and Cep152 are upregulated, and Gsn is $40 \%$ downregulated, which is consistent with reduced ciliated cell numbers in Gsn knockdown cells (Kim et al., 2010).

The BBs are disorientated in Ulk4 $4^{\text {tm Ia/tmla }}$ mice. Odf2, Nphp4, $P \mathrm{~cm} 1$, and Tmem67 are involved in BB formation and orientation (Ansley et al., 2003; Arts et al., 2007; Kunimoto et al., 2012; Leightner et al., 2013), and their expression is significantly increased in Ulk4 $4^{\text {tm la/tmla }}$ mice. In contrast, Nedd 1 is 30\% downregulated, in line with its critical role as a $\mathrm{BB}$ component at the root of ciliated microtubules (Manning et al., 2008). Vangll is also $33 \%$ downregulated. Interestingly, mutations of VANGL1 
have been identified in sporadic and familial neural tube defects (Kibar et al., 2007), and loss of Vangl2 causes neural tube defects in $L p / L p$ mice (Kibar et al., 2001). Therefore decreased expression of Nedd 1 and Vangl1 may contribute to misaligned BBs in Ulk4 mutants.

$U l k 4^{\text {tmla/tmla }}$ mice show defects in axoneme and motor function. Tubb4a, the predominant subtype of $\beta$-tubulins in the brain (Leandro-Garcia et al., 2010) is significantly reduced in Ulk4 mutants, and kinesin protein Kif5a as a microtubule motor is 19\% decreased. Dnal1 and Ttll6 are downregulated by 10 and $49 \%$, respectively, which is consistent with roles of Ttll6 in ciliary motility by modifying inner dynein arms (Suryavanshi et al., 2010), of DNAL1 as a component of outer dynein arms (Mazor et al., 2011), and identification of DNAL1 mutations in patients with CILD16 and motile cilia abnormalities (Mazor et al., 2011). Together, these data show that Ulk4 disruption results in disturbed balance of ciliogenesis genes, which consequently impairs cilia development, axoneme structure, and coordinated beating.

$U l k 4^{\text {tmla/tm1a }}$ mice also die early postnatally. Hydrocephalus may partially contribute to this, but peripheral defects are likely. ULK4 is associated with hypertension (Levy et al., 2009) and multiple myeloma (Broderick et al., 2012), but we have no evidence of tumor formation, or gross pathology of heart, liver, lung, kidney, and spleen. The stomachs of $U l k 4^{\text {tmla/tmla }}$ mice are smaller than normal and colored white, suggestive of reduced food intake. Functional disturbance of lung and kidney is likely, as motile cilia are critical for these organs. Interestingly, Stumpy (B9D2) mutation also leads to preweaning loss, perinatal hydrocephaly, defective ciliogenesis, as well as polycystic kidney disease (Town et al., 2008). In addition, Stumpy mutation compromises hippocampal neurogenesis (Breunig et al., 2008), and we discover a reduced neural stem cell pool in the Ulk4 mutants (Liu et al., 2016). However, Ulk4 does not appear to directly regulate $B 9 D 2$, and $109 \%(p=0.16)$ of B9D2 mRNA is detected in Ulk4 mutants.

The RNA sequencing data suggest that Ulk4 regulates Foxj1 expression, modulates Foxj1 target genes, including Spag6, Rsph9, Rsph4a, Dnah9, Dnal1, Ttll6 and Tekt 2, and influences axoneme structure. Ulk4 may also modify expression of many other ciliogenesis genes (i.e., Vangll, Nedd1, Odf2, Nphp4, Tmem67, Pcm1; Poc1b, Poc5, Cep120, Cep152; Tubb4a,
A Cilia master genes $B$
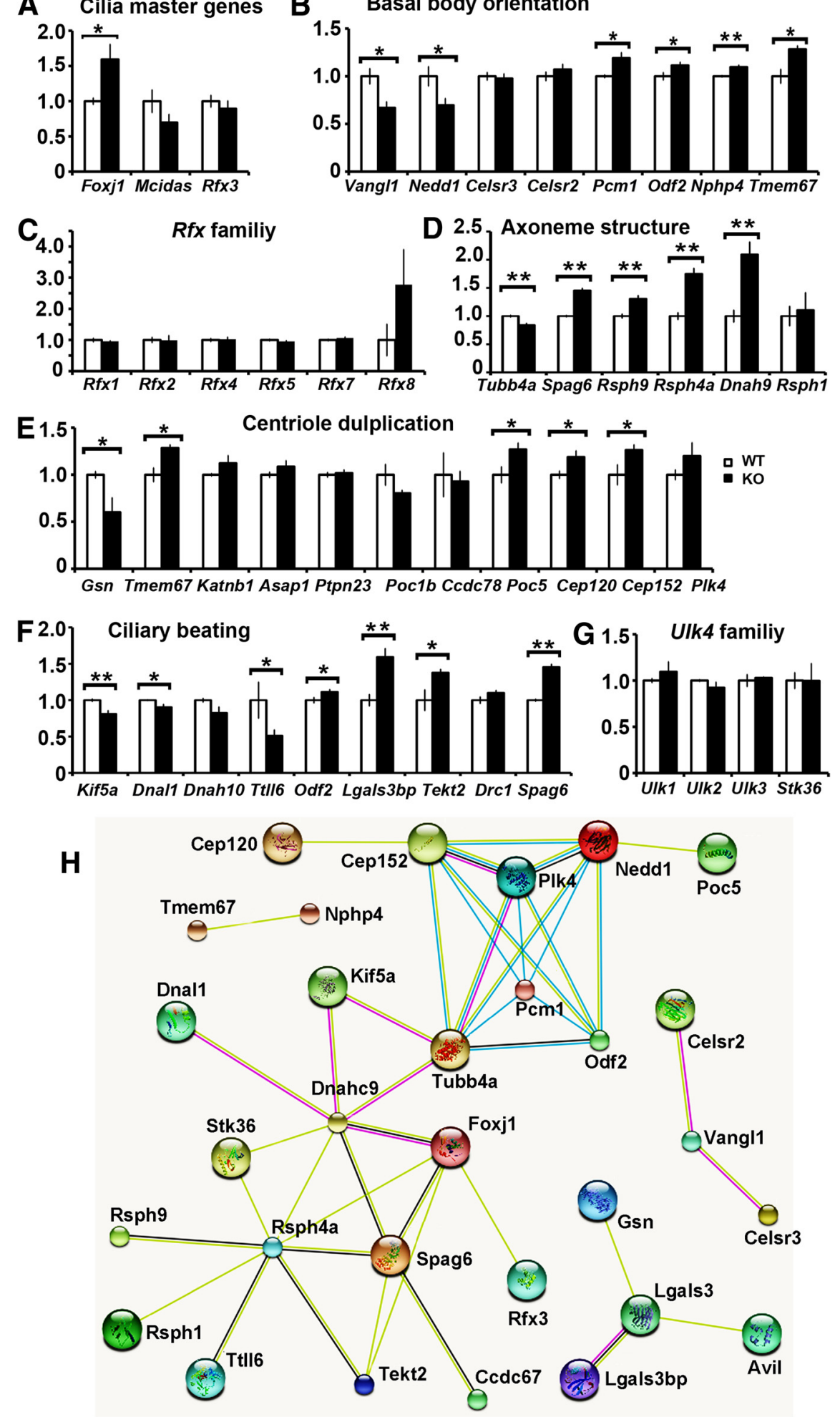

Figure 7. Changes in mRNA expression of genes associated with ciliary formation and function in Ulk4 $4^{\text {tm } 1 a / t m 1 a}$ mice. Wholegenome RNA sequencing was performed with P12 RNA from 3 WT and 3 knock-out (KO) cortices. Data were presented with folds of changes in the Ulk4 $4^{\text {tm } 1 a / t m 1 a}$ mice (KO/WT, mean \pm SEM). $A$, Ulk4 regulates Foxj 1 but not other (Rfx3, Mcidas) master ciliogenesis genes. $\boldsymbol{C}$, None of the other $R f x 3$ family members was significantly altered. $\boldsymbol{B}, \boldsymbol{D}-\boldsymbol{F}$, Key genes involved in $(\boldsymbol{E})$ centriole amplification, (D) axoneme ultrastructure, $(\boldsymbol{B})$ BB orientation, and $(\boldsymbol{F})$ ciliary beating were statistically analyzed. $\boldsymbol{G}$, The Ulk4 family members showed no compensation changes in expression. $\boldsymbol{H}$, STRING GO analyses of the 38 Ulk4 dysregulated genes showed that 32 of them are interconnected. ${ }^{*} p<0.05 ;{ }^{* *} p<0.01$. 
Gsn; Kif5a, Lgals3, Lgals3b) and thereby affect BB alignment, ciliary number, maturation, and beating. In summary, the current study revealed defects in the structure, abundance, organization, and function of ependymal motile cilia in Ulk4 $4^{\text {tmla/tmla }}$ mice, together with aqueduct obstruction, SCO dysfunction, and impaired CSF flow. This report, the first to comprehensively demonstrate that Ulk4 is crucial for survival, postnatal growth, and ciliogenesis, supports broad implications for the ULK4 gene in human conditions.

\section{References}

Al Jord A, Lemaittre AI, Delgehyr N, Faucourt M, Spassky N, Meunier A (2014) Centriole amplification by mother and daughter centrioles differs in multiciliated cells. Nature 516:104-107. CrossRef Medline

Ansley SJ, Badano JL, Blacque OE, Hill J, Hoskins BE, Leitch CC, Kim JC, Ross AJ, Eichers ER, Teslovich TM, Mah AK, Johnsen RC, Cavender JC, Lewis RA, Leroux MR, Beales PL, Katsanis N (2003) Basal body dysfunction is a likely cause of pleiotropic Bardet-Biedl syndrome. Nature 425:628-633. CrossRef Medline

Arts HH, Doherty D, van Beersum SE, Parisi MA, Letteboer SJ, Gorden NT, Peters TA, Märker T, Voesenek K, Kartono A, Ozyurek H, Farin FM, Kroes HY, Wolfrum U, Brunner HG, Cremers FP, Glass IA, Knoers NV, Roepman R (2007) Mutations in the gene encoding the basal body protein RPGRIP1L, a nephrocystin-4 interactor, cause Joubert syndrome. Nat Genet 39:882-888. CrossRef Medline

Brandler WM, Paracchini S (2014) The genetic relationship between handedness and neurodevelopmental disorders. Trends Mol Med 20:83-90. CrossRef Medline

Breunig JJ, Sarkisian MR, Arellano JI, Morozov YM, Ayoub AE, Sojitra S, Wang B, Flavell RA, Rakic P, Town T (2008) Primary cilia regulate hippocampal neurogenesis by mediating sonic hedgehog signaling. Proc Natl Acad Sci U S A 105:13127-13132. CrossRef Medline

Breunig JJ, Arellano JI, Rakic P (2010) Cilia in the brain: going with the flow. Nat Neurosci 13:654-655. CrossRef Medline

Broderick P, Chubb D, Johnson DC, Weinhold N, Försti A, Lloyd A, Olver B, Ma YP, Dobbins SE, Walker BA, Davies FE, Gregory WA, Child JA, Ross FM, Jackson GH, Neben K, Jauch A, Hoffmann P, Mühleisen TW, Nöthen MM, et al. (2012) Common variation at 3p22.1 and 7p15.3 influences multiple myeloma risk. Nat Genet 44:58-61. CrossRef Medline

Carter CS, Vogel TW, Zhang Q, Seo S, Swiderski RE, Moninger TO, Cassell MD, Thedens DR, Keppler-Noreuil KM, Nopoulos P, Nishimura DY, Searby CC, Bugge K, Sheffield VC (2012) Abnormal development of NG2+PDGFR-alpha + neural progenitor cells leads to neonatal hydrocephalus in a ciliopathy mouse model. Nat Med 18:1797-1804. CrossRef Medline

Chan EY, Longatti A, McKnight NC, Tooze SA (2009) Kinase-inactivated ULK proteins inhibit autophagy via their conserved C-terminal domains using an Atg13-independent mechanism. Mol Cell Biol 29:157-171. CrossRef Medline

Choksi SP, Lauter G, Swoboda P, Roy S (2014) Switching on cilia: transcriptional networks regulating ciliogenesis. Development 141:1427-1441. CrossRef Medline

Clare DK, Magescas J, Piolot T, Dumoux M, Vesque C, Pichard E, Dang T, Duvauchelle B, Poirier F, Delacour D (2014) Basal foot MTOC organizes pillar MTs required for coordination of beating cilia. Nat Commun 5:4888. CrossRef Medline

Collins P (1983) Morphological features of the surface of the subcommissural organ and aqueduct in the red necked wallaby (Wallabia rufogrisea). J Anat 137:665-673. Medline

Domínguez L, Schlosser G, Shen S (2015) Expression of a novel serine/threonine kinase gene, Ulk4, in neural progenitors during Xenopus laevis forebrain development. Neuroscience 290:61-79. CrossRef Medline

Egan DF, Shackelford DB, Mihaylova MM, Gelino S, Kohnz RA, Mair W, Vasquez DS, Joshi A, Gwinn DM, Taylor R, Asara JM, Fitzpatrick J, Dillin A, Viollet B, Kundu M, Hansen M, Shaw RJ (2011) Phosphorylation of ULK1 (hATG1) by AMP-activated protein kinase connects energy sensing to mitophagy. Science 331:456-461. CrossRef Medline

El Zein L, Ait-Lounis A, Morlé L, Thomas J, Chhin B, Spassky N, Reith W, Durand B (2009) RFX3 governs growth and beating efficiency of motile cilia in mouse and controls the expression of genes involved in human ciliopathies. J Cell Sci 122:3180-3189. CrossRef Medline
Fliegauf M, Benzing T, Omran H (2007) When cilia go bad: cilia defects and ciliopathies. Nat Rev Mol Cell Biol 8:880-893. CrossRef Medline

Fuccillo M, Joyner AL, Fishell G (2006) Morphogen to mitogen: the multiple roles of hedgehog signalling in vertebrate neural development. Nat Rev Neurosci 7:772-783. CrossRef Medline

Huh MS, Todd MA, Picketts DJ (2009) SCO-ping out the mechanisms underlying the etiology of hydrocephalus. Physiology (Bethesda) 24:117126. CrossRef Medline

Keller LC, Geimer S, Romijn E, Yates J 3rd, Zamora I, Marshall WF (2009) Molecular architecture of the centriole proteome: the conserved WD40 domain protein $\mathrm{POC} 1$ is required for centriole duplication and length control. Mol Biol Cell 20:1150-1166. CrossRef Medline

Kibar Z, Vogan KJ, Groulx N, Justice MJ, Underhill DA, Gros P (2001) Ltap, a mammalian homolog of Drosophila Strabismus/Van Gogh, is altered in the mouse neural tube mutant Loop-tail. Nat Genet 28:251-255. CrossRef Medline

Kibar Z, Torban E, McDearmid JR, Reynolds A, Berghout J, Mathieu M, Kirillova I, De Marco P, Merello E, Hayes JM, Wallingford JB, Drapeau P, Capra V, Gros P (2007) Mutations in VANGL1 associated with neuraltube defects. N Engl J Med 356:1432-1437. CrossRef Medline

Kim IH, Carlson BR, Heindel CC, Kim H, Soderling SH (2012) Disruption of wave-associated Rac GTPase-activating protein (Wrp) leads to abnormal adult neural progenitor migration associated with hydrocephalus. J Biol Chem 287:39263-39274. CrossRef Medline

Kim J, Lee JE, Heynen-Genel S, Suyama E, Ono K, Lee K, Ideker T, Aza-Blanc P, Gleeson JG (2010) Functional genomic screen for modulators of ciliogenesis and cilium length. Nature 464:1048-1051. CrossRef Medline

Kunimoto K, Yamazaki Y, Nishida T, Shinohara K, Ishikawa H, Hasegawa T, Okanoue T, Hamada H, Noda T, Tamura A, Tsukita S, Tsukita S (2012) Coordinated ciliary beating requires Odf2-mediated polarization of basal bodies via basal feet. Cell 148:189-200. CrossRef Medline

Laclef C, Anselme I, Besse L, Catala M, Palmyre A, Baas D, Paschaki M, Pedraza M, Métin C, Durand B, Schneider-Maunoury S (2015) The role of primary cilia in corpus callosum formation is mediated by production of the Gli3 repressor. Hum Mol Genet 24:4997-5014. CrossRef Medline

Lang B, Pu J, Hunter I, Liu M, Martin-Granados C, Reilly TJ, Gao GD, Guan ZL, Li WD, Shi YY, He G, He L, Stefánsson H, St Clair D, Blackwood DH, McCaig CD, Shen S (2014) Recurrent deletions of ULK4 in schizophrenia: a gene crucial for neuritogenesis and neuronal motility. J Cell Sci 127:630-640. CrossRef Medline

Leandro-Garcia LJ, Leskela S, Landa I, Montero-Conde C, Lopez-Jimenez E, Leton R, Cascon A, Robledo M, Rodriguez-Antona C (2010) Tumoral and tissue-specific expression of the major human beta-tubulin isotypes. Cytoskeleton (Hoboken) 67:214-223. CrossRef Medline

Lee EJ, Tournier C (2011) The requirement of uncoordinated 51-like kinase 1 (ULK1) and ULK2 in the regulation of autophagy. Autophagy 7:689695. CrossRef Medline

Lee JE, Gleeson JG (2011) Cilia in the nervous system: linking cilia function and neurodevelopmental disorders. Curr Opin Neurol 24:98-105. CrossRef Medline

Lee K, Tan J, Morris MB, Rizzoti K, Hughes J, Cheah PS, Felquer F, Liu X, Piltz S, Lovell-Badge R, Thomas PQ (2012) Congenital hydrocephalus and abnormal subcommissural organ development in Sox3 transgenic mice. PLoS One 7:e29041. CrossRef Medline

Leightner AC, Hommerding CJ, Peng Y, Salisbury JL, Gainullin VG, Czarnecki PG, Sussman CR, Harris PC (2013) The Meckel syndrome protein meckelin (TMEM67) is a key regulator of cilia function but is not required for tissue planar polarity. Hum Mol Genet 22:2024-2040. CrossRef Medline

Levy D, Ehret GB, Rice K, Verwoert GC, Launer LJ, Dehghan A, Glazer NL, Morrison AC, Johnson AD, Aspelund T, Aulchenko Y, Lumley T, Köttgen A, Vasan RS, Rivadeneira F, Eiriksdottir G, Guo X, Arking DE, Mitchell GF, Mattace-Raso FU, et al. (2009) Genome-wide association study of blood pressure and hypertension. Nat Genet 41:677-687. CrossRef Medline

Li C, Inglis PN, Leitch CC, Efimenko E, Zaghloul NA, Mok CA, Davis EE, Bialas NJ, Healey MP, Héon E, Zhen M, Swoboda P, Katsanis N, Leroux MR (2008) An essential role for DYF-11/MIP-T3 in assembling functional intraflagellar transport complexes. PLoS Genet 4:e1000044. CrossRef Medline

Liu M, Guan Z, Shen Q, Flinter F, Domínguez L, Ahn J-W, Collier DA, 
O’Brien T, Shen S (2016) Ulk4 regulates neural stem cell pool. Stem Cells, in press.

Manning JA, Colussi PA, Koblar SA, Kumar S (2008) Nedd1 expression as a marker of dynamic centrosomal localization during mouse embryonic development. Histochem Cell Biol 129:751-764. CrossRef Medline

Marley A, von Zastrow M (2012) A simple cell-based assay reveals that diverse neuropsychiatric risk genes converge on primary cilia. PLoS One 7:e46647. CrossRef Medline

Mazor M, Alkrinawi S, Chalifa-Caspi V, Manor E, Sheffield VC, Aviram M, Parvari R (2011) Primary ciliary dyskinesia caused by homozygous mutation in DNAL1, encoding dynein light chain 1. Am J Hum Genet 88: 599-607. CrossRef Medline

McAllister JP 2nd (2012) Pathophysiology of congenital and neonatal hydrocephalus. Semin Fetal Neonatal Med 17:285-294. CrossRef Medline

Merchant M, Evangelista M, Luoh SM, Frantz GD, Chalasani S, Carano RA, van Hoy M, Ramirez J, Ogasawara AK, McFarland LM, Filvaroff EH, French DM, de Sauvage FJ (2005) Loss of the serine/threonine kinase fused results in postnatal growth defects and lethality due to progressive hydrocephalus. Mol Cell Biol 25:7054-7068. CrossRef Medline

Millar JK, Wilson-Annan JC, Anderson S, Christie S, Taylor MS, Semple CA, Devon RS, St Clair DM, Muir WJ, Blackwood DH, Porteous DJ (2000) Disruption of two novel genes by a translocation co-segregating with schizophrenia. Hum Mol Genet 9:1415-1423. CrossRef Medline

Mitchell B, Jacobs R, Li J, Chien S, Kintner C (2007) A positive feedback mechanism governs the polarity and motion of motile cilia. Nature 447: 97-101. CrossRef Medline

Sawamoto K, Wichterle H, Gonzalez-Perez O, Cholfin JA, Yamada M, Spassky N, Murcia NS, Garcia-Verdugo JM, Marin O, Rubenstein JL, Tessier-Lavigne M, Okano H, Alvarez-Buylla A (2006) New neurons follow the flow of cerebrospinal fluid in the adult brain. Science 311:629632. CrossRef Medline

Skarnes WC, Rosen B, West AP, Koutsourakis M, Bushell W, Iyer V, Mujica
AO, Thomas M, Harrow J, Cox T, Jackson D, Severin J, Biggs P, Fu J, Nefedov M, de Jong PJ, Stewart AF, Bradley A (2011) A conditional knockout resource for the genome-wide study of mouse gene function. Nature 474:337-342. CrossRef Medline

Song H, Hu J, Chen W, Elliott G, Andre P, Gao B, Yang Y (2010) Planar cell polarity breaks bilateral symmetry by controlling ciliary positioning. $\mathrm{Na}-$ ture 466:378-382. CrossRef Medline

Suryavanshi S, Eddé B, Fox LA, Guerrero S, Hard R, Hennessey T, Kabi A, Malison D, Pennock D, Sale WS, Wloga D, Gaertig J (2010) Tubulin glutamylation regulates ciliary motility by altering inner dynein arm activity. Curr Biol 20:435-440. CrossRef Medline

Thomas J, Morlé L, Soulavie F, LaurençonA, Sagnol S, Durand B (2010) Transcriptional control of genes involved in ciliogenesis: a first step in making cilia. Biol Cell 102:499-513. CrossRef Medline

Tissir F, Qu Y, Montcouquiol M, Zhou L, Komatsu K, Shi D, Fujimori T, Labeau J, Tyteca D, Courtoy P, Poumay Y, Uemura T, Goffinet AM (2010) Lack of cadherins Celsr2 and Celsr3 impairs ependymal ciliogenesis, leading to fatal hydrocephalus. Nat Neurosci 13:700-707. CrossRef Medline

Town T, Breunig JJ, Sarkisian MR, Spilianakis C, Ayoub AE, Liu X, Ferrandino AF, Gallagher AR, Li MO, Rakic P, Flavell RA (2008) The stumpy gene is required for mammalian ciliogenesis. Proc Natl Acad Sci U S A 105:2853-2858. CrossRef Medline

Vladar EK, Bayly RD, Sangoram AM, Scott MP, Axelrod JD (2012) Microtubules enable the planar cell polarity of airway cilia. Curr Biol 22:22032212. CrossRef Medline

Vogel P, Read RW, Hansen GM, Payne BJ, Small D, Sands AT, Zambrowicz BP (2012) Congenital hydrocephalus in genetically engineered mice. Vet Pathol 49:166-181. CrossRef Medline

Yu X, Ng CP, Habacher H, Roy S (2008) Foxj1 transcription factors are master regulators of the motile ciliogenic program. Nat Genet 40:14451453. CrossRef Medline 